\title{
13
}

\section{Sir Arthur Tange: Departmental Reformer}

\author{
Peter Edwards
}

Sir Arthur Tange was remembered, especially in Canberra, long after his retirement, but very largely for his last position, as secretary of the Department of Defence throughout the 1970s. There are many in the military who have still not forgiven the author of 'the Tange report' and the instigator of 'the Tange reforms', which resulted not only in a fundamental reorganisation of the Defence group of departments but also in major changes to Australian strategic policies. Particularly among left-leaning journalists, there was a longstanding belief that Tange was the crucial link between the CIA and the Governor-General that led to the dismissal of the Whitlam Government in November 1975. Others long contended that he played a dishonourable role at the time of the deaths of five Australia-based journalists at Balibo, Portuguese Timor, in October 1975. Within the public service, anecdotes long endured of Tange's style, which would today be described as unacceptable bullying. Tange was capable of browbeating officers, even senior officers, in front of their subordinates, stopping just short of physical contact, throwing down files so that they disintegrated on the floorand then, in a split second, turning to welcome a visiting dignitary with wit and charm. Ever conscious of the importance of his own time, he would insist that a lift was kept available for his use, and Heaven help anyone who encroached on his parking space, even at a weekend. Wits liked to describe the Chinese floor vases outside his office as 'Late Tang - slightly cracked'.

The focus and span of this volume offer an opportunity to look anew at Tange's career as if, as very nearly happened, it had come to an end in the late 1960s, before his appointment to Defence. A study of Tange's career in the 1940s, 1950s and 1960s adds further evidence and nuances to some of the themes under consideration. These include the importance of the new cohort of university graduates, especially in economics, in the Commonwealth Public Service; the dedication to institution-building, especially strong departments, as a mark of the professionalism of the public service; and the simultaneous adherence to both the concept of an independent public service, giving frank and fearless advice to governments of whatever party, and a broadly social democratic ethos, embodied in the great project of post-war reconstruction. If we, for the 
moment, leave aside Tange's work in Defence in the 1970s, he remains important and distinctive, albeit not unique, for his role in taking these themes into the relatively new area, for the Commonwealth Public Service, of foreign policy.

Tange was born in the fateful month of August 1914. ${ }^{1}$ Although the youngest of seven siblings from his father's two marriages, Arthur was in many ways more like an only child than a member of a large family, and he long retained the psychological outlook of a loner. His grandfather, Anton Tange, migrated from Denmark in the 1850s and prospered as a tea merchant in Sydney; the next generation lost much of the family's fortune. Arthur's father, Charles, attended The King's School, Parramatta, and graduated from the University of Sydney, where he was a resident of St Paul's College, but discarded his promising practice as a lawyer in Sydney, with a house on the upper North Shore, to go on the land, establishing an orchard near Gosford on the Central Coast. This venture failed and Arthur's early years, when he attended Woy Woy Primary School and Gosford High School, were shaped by the impecunious circumstances. Tange was never close to his father, who was 54 when Arthur was born, but was always loyally supportive to his mother during her 40 years as a widow. The spur to Arthur's ambition was his determination not to fail his dependents in the way that his father had.

Despite good results in his matriculation examination, at the age of just 16, Arthur would have had little chance of following his father to university but for a stroke of fortune. His eldest sibling, his half-sister Dorothy, 22 years his senior, had married Alfred Davidson, who rose spectacularly in the 1920s to become general manager of the Bank of New South Wales, the position known today as the Chief Executive Officer of Westpac. Davidson, a dominant figure in Australian finance in the 1930s and early 1940s who did much to shape Australia's response to the Depression, became employer and mentor to his young brotherin-law. He gave Arthur a base-grade job in the bank, and then transferred him to the Perth branch so that he could attend the University of Western Australia, the only free university in Australia. Davidson was especially impressed with the dynamic professor of history and economics, E.O.G. (Ted) Shann.

In later life Tange liked to speak of the three great achievements of his time as a student in Perth. He gained post-graduate qualifications (as an honours degree was then regarded), gaining a Bachelor of Arts with first class honours in economics, with a thesis on the Australian capital market. (Essentially he argued that Australian banks were unduly conservative in lending to business; plus ça change.) Secondly, he became an outstanding rugby player, representing Western Australia against the visiting Springboks. Thirdly, he won the heart

1 For a fuller account of Tange than is provided here, see P. Edwards, Arthur Tange: Last of the Mandarins (Crows Nest, NSW: Allen \& Unwin, 2006). 
and, when he could afford it, the hand of Marjorie Shann, one of Professor Shann's three daughters. (Keith Shann, better known as Mick, was Marjorie's first cousin.)

After graduating, Arthur and Marjorie were both employed by Davidson in the bank's Economics Department, an in-house think tank established by Davidson with considerable influence from Ted Shann. Arthur was then posted to Fiji, where the bank had a profitable business in foreign exchange, and where Tange saw no reason to hold British colonial officials in high esteem. From there he was recruited to become what his employer and mentor, Davidson, had long held in low esteem - a Canberra public servant. Tange became a lowly research officer in that section of the Department of Labour and National Service, which was already looking at post-war policies. Later this became the Department of PostWar Reconstruction.

In Post-War Reconstruction, Tange became one of the team of officials working under senior economists such as Leslie Melville, L.F. Giblin and Douglas Copland. A principal focus was Article VII of the Lend-Lease agreement, which made American aid conditional upon working towards free trade. The Australians sought to reconcile this with their traditional policies of protectionism and imperial preference. In 1944 Tange, with Melville and his friend and contemporary Fred Wheeler, were the only three officials on the absurdly small and overworked delegation to Bretton Woods, which laid the foundations for the post-war international economic order. In all this work, Tange's admiration for the British and American officials fell short of being overawed. Neither then nor later would he be one who naturally genuflected before great and powerful friends and allies.

During the late 1930s and early 1940s, Australia had been developing the basis of a foreign office and diplomatic service, known as the Department of External Affairs. This was another channel through which bright young graduates - mostly men, in the days of the marriage bar - were recruited into the Commonwealth Public Service. That department was also giving attention to the problems of the post-war world, with Paul Hasluck the central figure. The two departments worked separately, but in the latter years of the war, when Evatt and his closest adviser, John Burton, became aware that the proposed United Nations Organization was likely to have an economic component, they realised that External Affairs needed to boost its economic capacity. For a time Arthur Tange was shared 50/50 between Post-War Reconstruction and External Affairs.

Immediately after the war, Tange was recruited full-time to a position in External Affairs at the diplomatic level of first secretary, then quite senior in the departmental hierarchy. He was promptly despatched to the Mission to the United Nations in New York. There, while Hasluck worked on Security Council and related matters, Tange worked not only on international economic questions 
but also on other fields. This was an era of international conferences establishing, and writing constitutions for, international organisations in a diverse range of fields. Tange rapidly developed expertise in these new aspects of international diplomacy, a new field for the Commonwealth Public Service.

Tange had thus joined the cohort of bright young graduates in External Affairs, but he was, from the start, a little apart from the rest. He had been laterally recruited, rather than coming up through the department's own cadet scheme, and his expertise was primarily in economics, unlike most of his new colleagues. He remained a little apart.

From New York, Tange returned to Canberra. Soon after the change of government in December 1949, the new minister for External Affairs, Percy Spender, recruited Tange as his principal adviser at the conference that devised what became the Colombo Plan. He was not, however, part of the official team who worked with Spender on what became the ANZUS Treaty, although he had some marginal involvement in those negotiations. Without over-emphasising the point, it is probably fair to say that, of the two pillars of Australian foreign policy that were erected during Spender's short but highly creative term, Tange remained closer to that which prescribed engagement with the region than to that of the US alliance.

Tange's next diplomatic posting, at an unusually senior level for someone of his years and experience, was as deputy head of mission at the embassy in Washington, where Spender had been made ambassador. Here his unwritten brief was to try to restrain Spender, who seemed (in the eyes of many in Canberra) to think that he was still minister rather than one of the new minister's official servants. In this exercise, Tange did not have much success, but the experience of working in Washington during the time of Senator Joe McCarthy did nothing to raise his estimation of American officialdom.

The age structure of External Affairs in the early 1950s was very unusual, with a tiny handful of diplomatic officers over the age of 40 and burgeoning numbers in their twenties and thirties. It was highly likely, therefore, that when one of the senior men, Alan Watt, retired as secretary in 1954, the baton would be passed to one of the junior men. In the event, the minister, R.G. Casey, evidently considered two of the senior men, Keith Officer and Alfred Stirling, but both wisely considered that they were not well suited to the post. Casey chose Tange, just ahead of Jim (later Sir Laurence) McIntyre and the three who would become Tange's principal lieutenants, Keith Waller, Pat Shaw and James Plimsoll. Others in the same cohort included Peter Heydon, Keith 'Mick' Shann and Ralph Harry, all of whom became departmental heads and/or senior ambassadors in the coming years. (Waller, Shaw, Plimsoll, Heydon and Shann were all later knighted; Harry was appointed AC.) 


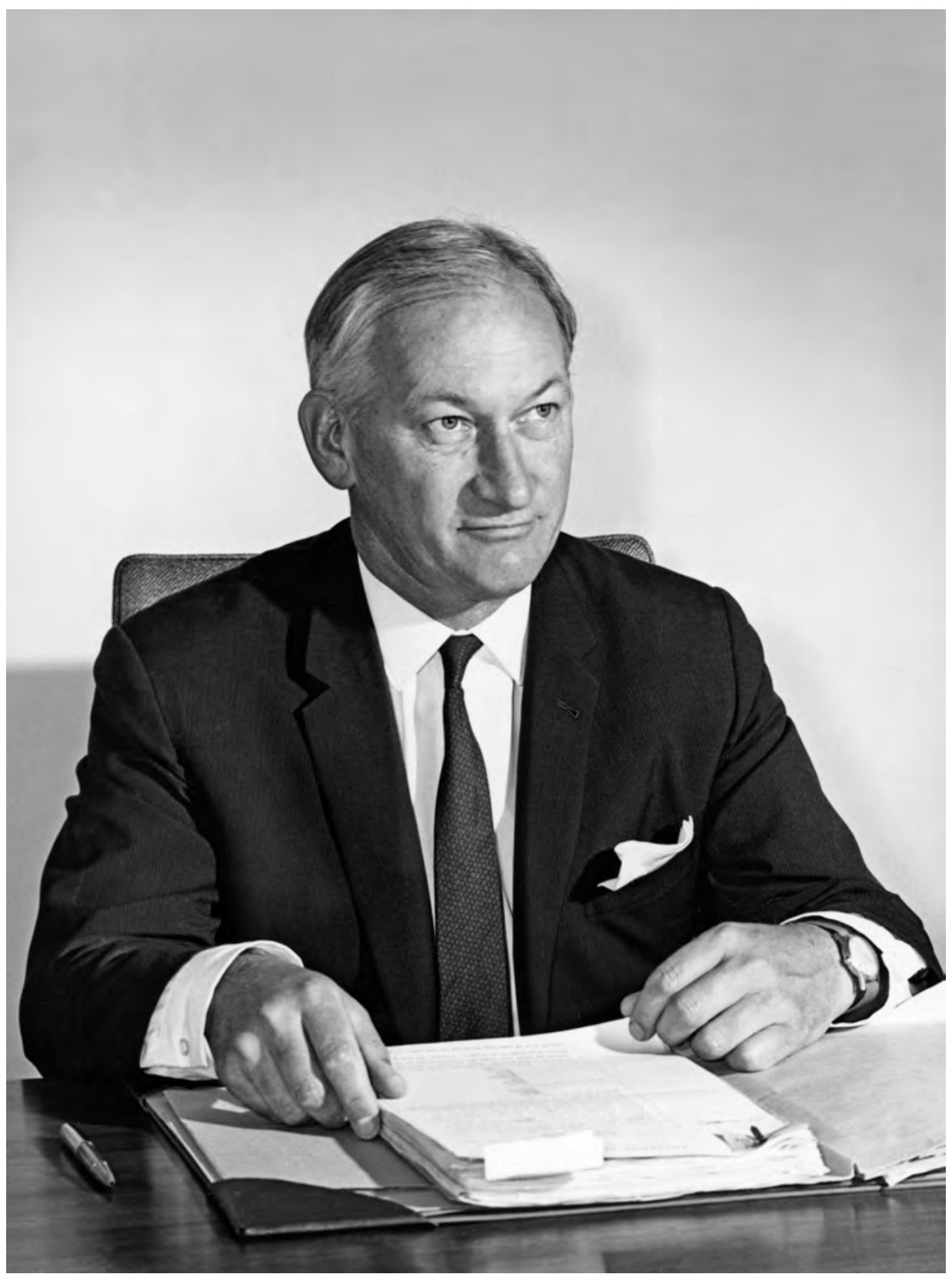

Sir Arthur Tange, 1965

Source: National Archives of Australia, A8947, 45 
Tange remained secretary of the Department of External Affairs for 11 years, starting with the Petrov Affair and the rupture of relations with the Soviet Union and ending just as Australia was about to commit combat troops to Vietnam. Typically, for a man who liked to work with the written word, Tange wrote two papers early in his tenure, one on administration and one on policy, which did much to establish the framework for his term as secretary.

Tange spent much of his time reorganising the department's structures and methods, with the aim of turning a group of more or less talented individuals into an effective and cohesive foreign office and diplomatic service. He initiated a wide range of major and minor reforms, some of which were remarkable largely for their previous absence - systems for appointments and promotions, performance appraisal, records of conversations, financial management and so on. Tange made it clear that he wanted the officers in External Affairs to put aside some of the pretensions to which ambitious diplomats were susceptible and to think of themselves first and foremost as public servants, competent and qualified in all the skills and responsibilities of good public servants, and then applying those skills and meeting those responsibilities in the field of foreign policy. At a time when the department was explicitly divided into Group A, the diplomatic officers, and Group B, the administrative and consular officers, this approach won the respect of the Group B officers but did not always endear Tange to the diplomats.

In establishing a professional foreign office and diplomatic service, Tange was obliged to accept three elements in the department that he thought did not properly belong there. In each case Tange's reservations, shared by his diplomatic colleagues, were overridden by Casey, a much admired and personally respected minister but one whose enthusiasms often frustrated his officers. These three elements were the Australian Secret Intelligence Service, the Antarctic Division, and the implementation of the Colombo Plan. Tange would doubtless approve of the current situation, under which ASIS is an autonomous agency, separate from the department but reporting to the same minister, while the Antarctic Division is placed in the Department of the Environment. It is less likely that he would have approved of the 2013 decision to re-integrate AusAID into the Department of Foreign Affairs and Trade.

Whatever setbacks he may have had, the department was certainly far more effective at the end of his 11 years as secretary than it had been at the beginning.

Tange's policy document was notable for the priority it gave to relations with Asia and the comparative downplaying of relations with the United Kingdom and the United States, at a time when Prime Minister Menzies and his government placed pronounced emphasis on these 'great and powerful friends'. In policy matters, Tange and the department experienced both success and failure. 
An early attempt to have the government reconsider its attitude towards the recognition of the People's Republic of China was clumsily handled by Casey and the department, setting back policy on this critical issue for many years. Perhaps the greatest achievement was the handling of Konfrontasi, the low-level conflict between Indonesia and the new federation of Malaysia between 1963 and 1966. The minister, Garfield Barwick, the department in Canberra, and the missions in Jakarta and Kuala Lumpur worked extremely effectively to shape and implement a policy that was by no means always consistent with the instincts and attitudes of the long-serving and dominant prime minister, Menzies.

Tange's ministers during his term as secretary were some of the most significant Liberals of their era-Casey, Menzies himself, Barwick and Hasluck. His relations with them ranged from cordial to frosty, illustrating the degree to which the relationship between departmental head and minister depended on matters quite separate from party. Tange and his officers, for example, found Barwick almost an ideal minister, whereas their relations with their former colleague, Hasluck, when he returned as minister, were highly strained. I have considered these relationships in some detail in Arthur Tange: Last of the Mandarins. The relationship between Tange and Hasluck over some four decades would make an interesting study in itself.

Tange's relations with other public servants covered in this volume also ranged widely, from emulation through admiration and friendly, or not so friendly, rivalry to hostility and even contempt. He greatly admired H.C. 'Nugget' Coombs from his first exposure to Nugget's persuasive ways with Wall Street bankers; he thought that Frederick Shedden by the 1950s was well past his wartime prime and a failure at running the post-war Defence Department; he clashed with Wilson and his deputy, Lenox Hewitt, over the Treasury's control of departmental finances; he had a complex friendship-cum-rivalry with Fred Wheeler and a more distant respectful rivalry with J.G. Crawford (Tange and Crawford were knighted on the same day); and he thought Ken Bailey was able but weak in standing up to ministers.

Tange had been highly regarded by Menzies in the late 1950s, but by the early 1960s the prime minister was clearly seeking to move him onwards. Tange resisted this pressure, as a permanent head could do in those days, but he finally agreed in 1965 to become high commissioner to India. For some years, he thought that his career might end there, as he was determined not to accept any position below what he thought appropriate. Then, in what reads like an episode of Yes, Minister, he was rapidly offered the embassy in Washington, a return to his position in External Affairs, and the secretaryship in Defence. He spent the last 10 years of his career in the last position, undoubtedly the most remarkable occupant of the position to that point - and perhaps ever, because the public service reforms of the 1980s were brought in precisely to ensure that 
no departmental secretaries would ever again have the clout that was held, in fact and even more in reputation, by Tange, Wheeler and a handful of their cronies. That is why my biography of Tange is subtitled The Last of the Mandarins; but it is timely to recall that he contributed much to the strengths and, indeed, the weaknesses, of the public service in the 1940s, 1950s and 1960s. 
This text is taken from The Seven Dwarfs and the Age of the Mandarins: Australian Government Administration in the Post-War Reconstruction Era, edited by Samuel Furphy, published 2015 by ANU Press, The Australian National University, Canberra, Australia. 